\title{
Book Alert
}

World Digital Libraries 7(2): 157-158 (2014)

\section{A Handbook of Digital Library Economics, 1st Edition: Operations, Collections and Services}

Baker, David \& Evans, Wendy. 2013

Chandos Publishing, Oxford. 284p

This book provides a companion volume to Digital Library Economics and focuses on the 'how to' of managing digital collections and services with respect to their financing and financial management. The emphasis is on case studies and practical examples drawn from a wide variety of contexts. A Handbook of Digital Library Economics is a practical manual for those involved-or expecting to be involved - in the development and management of digital libraries.

\section{Library Analytics and Metrics: Using data to drive decisions and services}

Showers, Ben. 2015 Facet Publishing, UK. $224 p$

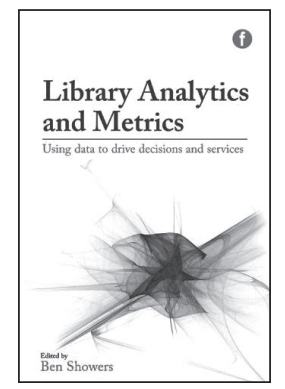

With the wealth of data available to library and information services, analytics are the key to understanding one's users and one's field of operations better and improving the services that one offers. This book sets out the opportunities that analytics present to libraries, and provides inspiration for how they can use the data within their systems to help inform decisions and drive services.

\section{Maxwell's Handbook for RDA: Explaining and Illustrating RDA: Resource Description and Access Using MARC21}

Maxwell, Robert L. 2013

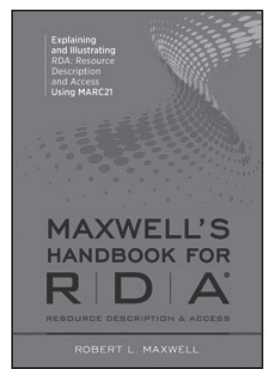

ALA Editions, Chicago. 912p

This handbook is winner of the 2014 ABCCLIO Library Publishing Award. In this clear and comprehensive resource, cataloguing expert Robert L Maxwell brings his trademark practical commentary to bear on the new, unified cataloguing standard. Designed to interpret and explain RDA: Resource Description and Access, this handbook illustrates and applies the new cataloguing rules in the MARC21 environment for every type of information format. 


\section{Big Data: A Revolution That Will Transform How We Live, Work, and Think}

Mayer-Schönberger, Viktor \& Cukier, Kenneth. 2014

Eamon Dolan/Mariner Books. 272p

It seems like "big data" is in the news every day, as we read the latest examples of how powerful algorithms are teasing out the hidden connections between seemingly unrelated things. Whether it is used by the NSA to fight terrorism or by online retailers to predict customers' buying patterns, "big data" is a revolution occurring around us. Big Data: A Revolution That Will Transform How We Live, Work, and Think is the first major book about this earth-shaking subject, with two leading experts explaining what big data is, how it will change our lives, and what we can do to protect ourselves from its hazards.
The Preservation and Protection of Library Collections, 1st Edition: A Practical Guide to Microbiological Controls

Zerek, Bogdan. 2014

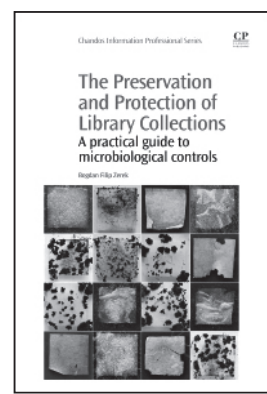

Chandos Publishing, Cambridge, 482p

Preservation involves a complex of activities including climate, air-quality, and surface control, as well as microbiological control, which is a key part of preserving and protecting library collections. The Preservation and Protection of Library Collections examines microbiological control for preservation of library and archival collections. A supporting tool for conservators, this title should be integrated into conservation and preservation policy. The book comprises nine sections that cover three aspects: microbiology, surveying, and the response required. Chapters in this title cover the nature of the library collections, physical and chemical factors, and their impact on microbiological issues, as well as biological factors and methods of microbiological control of the air and objects. Later chapters examine methods of object disinfection, disaster response, methods of microbiological control, and evaluation of collections, and includes a vocabulary guide, appendices, literature information, and references. 